\title{
THERAPY EFFECT OF RED DRAGON FRUIT (Hylocereus polyrhizus) PEEL EXTRACT TO INCREASE THE NUMBER OF SERTOLI CELLS ON BALB/c MICE (Mus musculus) EXPOSED TO LEAD ACETATE
}

\author{
Evy Wulandari ${ }^{1}$, Reny I'tishom ${ }^{2}$, Sri Agus Sudjarwo ${ }^{3}$ \\ ${ }^{1}$ Master Program of Reproductive Health Science, ${ }^{2}$ Department of Medical Biology, Faculty of Medicine, \\ ${ }^{3}$ Department of Pharmacology, Faculty of Veterinary Medicine, Universitas Airlangga, Surabaya, Indonesia
}

\section{ABSTRACT}

Lead is the free radicals and heavy metals of major pollutants in the environment. Lead is toxic and cumulative. Red dragon fruit (Hylocereus polyrhizus) peel extract is a natural antioxidant. Red dragon fruit peel extract can be used to stabilize free radicals by supplementing electron deficiencies and inhibiting chain reactions. This study aimed to analyze therapy effect of red dragon fruit peel extract to increase the number of Sertoli cells on BALB/c mice (Mus musculus) exposed to lead acetate. Fourty mice were divided into 5 groups (each group consisted of 8 mice). K- group was the control group without lead acetate and dragon fruit peel extract administration, $K+$ group was given $100 \mathrm{mg} / \mathrm{KgBW}$ lead acetate orally on the 1 st day until day 14th.. P1, P2, and P3 group were continued with red dragon extract orally on the 15th day until 39th day. P1 with dose 250 $\mathrm{mg} / \mathrm{KgBW}$, P2 with dose $500 \mathrm{mg} / \mathrm{KgBW}$, and P3 with dose $1000 \mathrm{mg} / \mathrm{KgBW}$. The result showed significant difference $(P<0.05)$ in the number of Sertoli cells between $K+$ and P1, P2, P3 group. In conclusion, dose $500 \mathrm{mg} / \mathrm{kg} B W$ of red dragon fruit peel extract can be used as the most effective therapy to increase the number of Sertoli cells on mice exposed to acetate lead.

Keywords: Lead acetate; red dragon fruit peel extract; Sertoli cells

\section{ABSTRAK}

Timbal adalah radikal bebas dan logam berat bahan pencemar utama di lingkungan. Timbal bersifat toksik dan kumulatif. Kulit buah naga merah (Hylocereus polyrhizus) merupakan antioksidan alami. Kulit buah naga merah dapat menstabilkan radikal bebas dengan melengkapi kekurangan elektron dan menghambat terjadinya reaksi berantai. Penelitian ini untuk menganalisis efek terapi ekstrak kulit buah naga merah terhadap jumlah sel Sertoli mencit (Mus musculus) BALB/c yang dipapar timbal asetat. Empat puluh ekor mencit dibagi menjadi 5 kelompok (setiap kelompok 8 mencit). K- tanpa timbal asetat dan ekstrak kulit buah naga merah. $K+$ diberi timbal asetat $100 \mathrm{mg} / \mathrm{kgBB}$ per oral hari ke-1 sampai hari ke-14. P1, P2 dan P3 dilanjutkan dengan pemberian ektrak kulit buah naga merah hari ke-15 sampai hari ke-39. P1 dengan dosis $250 \mathrm{mg} / \mathrm{kgBB}, \mathrm{P} 2$ dengan dosis 500mg/kgBB, P3 dengan dosis $1000 \mathrm{mg} / \mathrm{kgBB}$. Hasil penelitian menunjukkan ada perbedaan signifikan pada jumlah sel Sertoli antara kelompok K+ dengan P1, P2, dan P3. Kesimpulan penelitian ini adalah dosis $500 \mathrm{mg} / \mathrm{kgBB}$ dari ekstrak kulit buah naga merah dapat digunakan sebagai terapi paling efektif untuk meningkatkan jumlah sel Sertoli mencit yang dipapar timbal asetat.

Kata kunci: Timbal asetat; ekstrak kulit buah naga merah; sel Sertoli

Correspondence: Reny I'tishom, Department of Medical Biology, Faculty of Medicine, Universitas Airlangga, Jl. Prof Moestopo 47, Surabaya 60131. Telp: 08121644432. E-mail: ritishom@ @k.unair.ac.id

pISSN:2355-8393 • eISSN: 2599-056x • doi: http://dx.doi.org/10.20473/fmi.v56i2.21228

- Fol Med Indones. 2020;56:108-113 • Received 20 Apr $2018 \bullet$ Accepted 18 Oct 2018

- Open access under CC-BY-NC-SA license • Available at https://e-journal.unair.ac.id/FMI/

\section{INTRODUCTION}

Lead or plumbum $(\mathrm{Pb})$ is the main heavy metal pollutant in the environment (Naria 2005). Data from the Indonesian Ministry of Environment states that the use of lead on motor vehicles $(70 \%)$ is the main cause of lead pollution in the environment in several big cities in Indonesia (Suparwoko \& Firdaus 2007). Motor vehicle fuel (gasoline) contains more than $95 \%$ of lead used as an anti knocking (Ardyanto 2005). Lead in fuel is not burned during the combustion process of motor vehicles. This causes the amount of lead that is emitted into the air can become very high for long periods of time and is cumulative in the body (Palar 2008). Lead is also present in industries such as batteries, paint, rubber, ceramics, cable coatings, printing, water pipes, insecticides and cosmetics (WHO 2007). 
Lead and its compounds that enter the body through respiration, digestion, and skin exposure (Ardyanto 2005) can cause infertility in men (Panggabean et al 2008). Several studies have shown that male infertility can be caused by lead exposure at lower concentrations than those established by WHO (Mayo 2005, Telisman et al 2000). The air intake threshold set by WHO is 0.5 $\mu \mathrm{g} / \mathrm{m} 3$ (Panggabean et al 2008). The study by I'thisom et al (2011) shows that exposure to lead in men exposed to motor vehicle exhaust emissions can affect male fertility. This is evidenced by the inverse correlation of sperm concentrations with lead levels in the blood. Administration of acetate lead $100 \mathrm{mg} / \mathrm{kgBW}$ mice for 14 days affected the number of Sertoli mice cells (Almarmudah 2009).

Lead affects male fertility because lead can cause lipid peroxidation induced by oxidative stress. Lead in the blood circulation will bind to the delta-Aminolevulinic Acid Dehydratase (ALAD) enzyme and cause Aminolevulinic Acid (ALA) to increase. This causes an increase in reactive oxygen species (ROS). Excessive ROS causes antioxidant deposits in the body to decrease. This causes oxidative stress. Oxidative stress can occur through two mechanisms namely pratesticular mechanism and testicular mechanism (Hsu \& Guo 2002, Sudarmaji et al 2006). In the pratesticular mechanism, lead passes the blood-brain barrier and disrupts the metabolism of nerve cells through inhibition of nerve cell mitochondrial respiration. This causes a disruption to the axis of the hypothalamus-pituitary-testis. This causes GnRH secretion that affects Sertoli cells is decreased (Murray et al 2003, Camin 1993, Adikwu et al 2013). In the testicular mechanism, lead passes the testicular blood barrier and damages Leydig cells (contributes to the formation of testosterone) or Sertoli cells (produces androgen binding protein (ABP) and affects spermatogenesis processes) (Camin 1993, Defalco et al 2013).

Lead induces lipid oxidation (especially the chain of unsaturated fatty acids). Lead forms radical products such as peroxyl free radicals, PUFA free radicals, and superoxide free radicals. Increasing the number of these radicals causes the decomposition of unsaturated fatty acids into highly unstable lipid peroxides (Acharya et al 2003). The lipid peroxidation reaction can be inhibited by the addition of antioxidants, a substance that can bind to free radicals (Lyn 2006).

There are two types of antioxidants, namely synthetic antioxidants and natural antioxidants. The use of synthetic antioxidants is reduced because it can cause carcinogens. its use is replaced by natural antioxidants derived from cheap fruits or vegetables and few side effects (Flora et al 2012). One source of natural antioxidants is red dragon fruit peel (Hylocereus polyrhizus $)$. Red dragon fruit peel $(1 \mathrm{mg} / \mathrm{kg})$ is able to inhibit $83.48 \%$ of free radicals (Nurliyana et al 2010). Red dragon fruit peels has antioxidant activity (IC50 = 43,836 microgram/mL) (Mitasari 2012). Antioksidant of red dragon fruit peel is higher than its flesh.Red dragon fruit peel contains natural antioxidant compound in the form of phenolic or polyphenolic (Wu, et al., 2006). It has antioxidant activity of flavones, flavonols, isoflavones, catechins and kalkon (Prakash 2001, Kumalaningsih 2006) Red dragon fruit peel also contains betacyanin (Wu et al 2006). Betacyanin is part of the pigment betalaine and has antioxidant properties (neutralizing free radicals) (Martinez 2011) Betacyanin of red dragon fruit peel including phenolic compounds (Vermerris \& Nicholson 2006). Phenolic derivatives or polyphenols (as antioxidants) stabilize free radicals by supplementing lack of electrons possessing free radicals and inhibiting the occurrence of chain reactions from free radical formation (Hattenschwiler \& Vitousek 2000).

Therapy effect of red dragon fruit peel extract to increase the number of Sertoli cells have not been studied. This study will examine therapy effect of red dragon fruit peel extract to increase the number of Sertoli cells of BALB/C mice exposed to lead acetate.

\section{MATERIALS AND METHODS}

\section{Tools and materials}

The research tool includes cage pen, sonde, scales, disposible syringe, set of sterile surgical instrument, glass object, and light microscope. The research materials included male BALB/c mice (Mus musculus) aged 8-10 weeks weighing 30-40 grams obtained from Biochemistry Laboratory, Faculty of Medicine, Universitas Airlangga. The solution of red dragon fruit peel extract obtained from Laboratory Phytochemical UPT Materia Medica Stone, including lead acetate solution, Phosphate Buffer Shaline (PBS), ether, sterile aquadest, diluent solution ( $\mathrm{NaCl} 0.9 \%)$, NaCMC $0.5 \%$, $70 \%$ alcohol, $80 \%$, 96\%, buffer liquid paraffin formaldehyde, hemactosiline, eosin.

\section{Experimental animals and treatment}

Subjects were 40 male BALB/c mice (Mus musculus) strain with criteria of 8-10 weeks old, 30-40 gram weight, and healthy physical condition. The mice were divided into 5 groups, 2 controls and 3 treatments, each of which amounted to 8 mice. Experimental animals were acclimatized by placing mice in the cage for 1 week. K- group was the control group without lead 
acetate and red dragon fruit peel extract administration, $\mathrm{K}+$ group was given $100 \mathrm{mg} / \mathrm{KgBW}$ lead acetate orally on the 1st day until day 14th.. P1, P2, and P3 group were continued with red dragon peel extract orally on the 15th day until 39th day. P1 with dose 250 $\mathrm{mg} / \mathrm{KgBW}$, P2 with dose $500 \mathrm{mg} / \mathrm{KgBW}$, and P3 with dose $1000 \mathrm{mg} / \mathrm{KgBW}$. Mice were sacrificed on the 40th day. The mice were terminated with anesthesia using chloroform and then performed surgery to take the testicles. The testes were stored in pots filled with formalin and then made testicular histology. Testicular histologic preparations were observed under microscope with 400x magnification to measure the number of Sertoli cells. This study has earned the certificate of ethical eligibility from the Research Ethics Committee, Faculty of Veterinary Medicine, Airlangga University, Surabaya.

\section{Statistic analysis}

Data of the results were presented in mean and standard deviation, also in histogram. Assessment of data distribution used Kolmogorov-Smirnov test. Data distribution was normal if $\mathrm{p}$ value $=0.05$. Normally distributed data were analyzed by one-way ANOVA test. Furthermore, the results were analyzed using PostHoc LSD (Least Significant Difference) test.

\section{RESULTS}

The results showed that significant differences in the number of Sertoli cells in mice between group $\mathrm{K}$ - with $\mathrm{K}+$, group $\mathrm{K}$ - with $\mathrm{P} 2$, group $\mathrm{K}$ - with $\mathrm{P} 3$, group $\mathrm{K}+$ with $\mathrm{P} 1$, group $\mathrm{K}+$ with $\mathrm{P} 2$, group $\mathrm{K}+$ with $\mathrm{P} 3$, group $\mathrm{P} 1$ with $\mathrm{P} 2$, group $\mathrm{P} 1$ with $\mathrm{P} 3$, and group $\mathrm{P} 2$ with $\mathrm{P} 3$ (Table 1).

Figure 1 shows that Sertoli cells of the $\mathrm{K}+$ group decreases in comparison with the $\mathrm{K}$-group. Its means that the administration of lead acetate $100 \mathrm{mg} / \mathrm{kgBW}$ on the 1st day until day 14th can decrease the number of Sertoli cells. Sertoli cells of all red dragon fruit peel extract groups (P1, P2, P3) increased when compared to the $\mathrm{K}+$ group. $\mathrm{P} 2$ group had the highest percentage.

Table 1. Effect of red dragon fruit peel extract therapy (Hylocereus polyrhizus) on the number of Sertoli cells mice (Mus musculus) BALB/c exposed to lead acetate

\begin{tabular}{lc}
\hline \multicolumn{1}{c}{ Groups } & $\begin{array}{c}\text { The number of Sertoli cells } \\
\text { Mean } \pm \text { SD }\end{array}$ \\
\hline Negative control & $10.38^{\mathrm{a}} \pm 0.744$ \\
Positive control & $8.00^{\mathrm{b}} \pm 1.069$ \\
Red dragon fruit peel extract $250 \mathrm{mg} / \mathrm{kgBW}$ & $10.38^{\mathrm{c}} \pm 0.916$ \\
Red dragon fruit peel extract $500 \mathrm{mg} / \mathrm{kgBW}$ & $12.38^{\mathrm{d}} \pm 1.408$ \\
Red dragon fruit peel extract $1000 \mathrm{mg} / \mathrm{kgBW}$ & $9.25^{\mathrm{e}} \pm 1.282$ \\
\hline
\end{tabular}

Different superscript letters show significant differences at $\mathrm{p}<0.05$

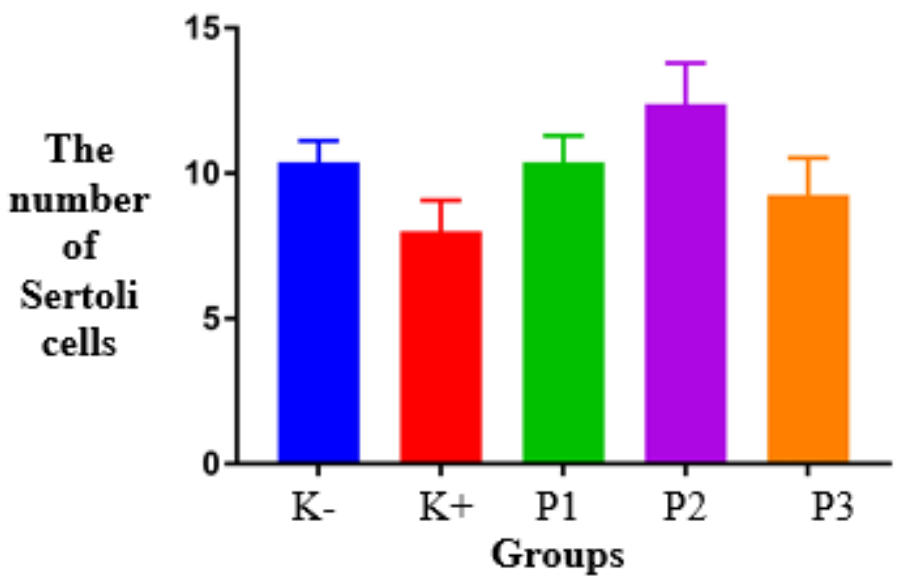

Fig. 1. Effect of red dragon fruit peel extract (Hylocereus polyrhizus) on the number of Sertoli cells mice (Mus musculus) BALB/c exposed to lead acetate. K-: negative control group; $\mathrm{K}+$ : positive control group; P1: group of red dragon fruit peel extract $250 \mathrm{mg} / \mathrm{kgBW}$; P2: group of red dragon fruit peel extract $500 \mathrm{mg} / \mathrm{kgBW}$; P3: group of red dragon fruit peel extract $1000 \mathrm{mg} / \mathrm{kgBW}$. 
It means that the administration of red dragon peel extract orally on the 15 th day until 39th day can increase the number of Sertoli cells mice exposed to lead acetate. Group of red dragon fruit peel extract 500 $\mathrm{mg} / \mathrm{kgBW}$ is the most effective therapy to increase the number of Sertoli cells on mice exposed to acetate lead.

\section{DISCUSSION}

The results of this study showed that administration of red dragon fruit peel extract (Hylocereus polyrhizus) in male BALB/c mice exposed to lead acetate can significantly increase Sertoli cells count and 500 $\mathrm{mg} / \mathrm{kg} /$ day dose is the most effective dose of extract red dragon fruit skin to produce the best Sertoli cell number.

The results of this study showed that lead acetate significantly affect Sertoli cells in accordance with the research of Bustos-Obregon and Hartley (2008) and Shan et al (2009). Shan et al (2009) explained that lead can decrease the number of Sertoli cells in the testes. This happens because lead can affect Sertoli cell microtubules and is followed by a decrease in fluid secretion of seminiferous tubules. The fluid has a role in providing nutrients and hormones in regulating the growth and differentiation of germ cells. Damage of Sertoli cells will inhibit the process of spermiogenesis and spermatogenesis so that sperm concentration decreases. Disorders of Sertoli cells inhibit the regeneration and maturation of germ cells that will cause the death of germ cells through the mechanism of apoptosis (Mahriani 2008).

Red dragon fruit peel has high antioxidant activity. High antioxidant activity will be supported by the number of bioactive compounds contained in the extract. Potential bioactive compounds as antioxidants in red dragon fruit peel include vitamin $\mathrm{C}$, carotenoids, vitamin $\mathrm{E}$, vitamin B, flavonoids, and polyphenols (Le Bellec et al 2006). Vitamin $\mathrm{C}$ is one type of secondary antioxidant that is widely used for the health of the body. Vitamin $\mathrm{C}$ is polar and volatile. Secondary antioxidants can protect cells or tissues from oxidative stress due to exposure to free radicals. Vitamin $\mathrm{C}$ is able to inhibit the oxidation of lipids, proteins, and DNA in the body that can lead to mutations (Murat et al 2014).

Carotenoid content of red dragon fruit contribute red color on the flesh and red dragon fruit peel. In addition to its role as a natural antioxidant, carotenoids can act as immune systems, xenobiotic metabolism, anti aging, and protection against UV rays (Roman et al 2013). Antosianin is one type of flavonoid that is found in dragon fruit (Jamilah et al 2011). Anthocyanins are believed to have excellent antioxidant effects.
Anthocyanins can destroy free radicals, more effective than vitamin $\mathrm{E}$ which has been known as a powerful antioxidant (Winarno 1997). Antosianin is the most powerful antioxidant among other flavonoid classes. The anthocyanin content is believed to inhibit a variety of free radicals such as superoxide radicals and hydrogen peroxide. Antosianin and its various derivative forms can inhibit various oxidation reactions by various mechanisms (Astawan \& Kasih 2008).

Flavonoids is phenolic compounds that can prevent oxidative stress. Flavonoids can inhibit the enzyme which has responsible for producing superoxide anion radicals, terminate reactions and extinguish the superoxide anion radicals (Pieta 2000). The mechanism of flavonoids as antioxidants occurs either directly or indirectly. The direct mechanism is inhibiting the oxidation process by initiation inhibition and propagation of the oxidation reaction of free radicals. Flavonoids in red dragon fruit peel extract contribute hydrogen atoms to capture hydroxyl radicals so they become nonreactive and inhibit free radicals (Amic et al 2003).

Indirect mechanisms is increasing the expression of endogenous antioxidant genes through several mechanisms. Flavonoids increase the expression of endogenous antioxidant genes through the activation of nuclear factor erythroid 2 related factor 2 (Nrf2) resulting in an enhancement of genes that play a role in the synthesis of endogenous antioxidant enzymes such as the SOD gene (Sumardika \& Jawi 2012). Flavonoids in certain circumstances may also exhibit prooxidant activity and it is directly proportional to the total number of hydroxyl groups (Cao et al 1997).

Prooxidants occur because of too high concentrations of antioxidants (Bouayed \& Bohn 2010). The antioxidant dose given, its affect on the rate of oxidation. A high concentration of antioxidants causes antioxidant activation to often disappear. This is why in this study found that at a dose of $1000 \mathrm{mg} / \mathrm{kg} /$ day resulted in a lower number of Sertoli cells than the dose of 500 $\mathrm{mg} / \mathrm{kg} /$ day.

\section{CONCLUSION}

A dose of $500 \mathrm{mg} / \mathrm{kg} \mathrm{BW}$ of red dragon fruit peel extract can be used as the most effective therapy to increase the number of Sertoli cells of mice exposed to acetate lead. 


\section{REFERENCES}

Acharya UR, Acharya S, Mishra M (2003). Lead acetate induced cytotoxicity in male germinal cells of Swiss mice. Industrial Health 41, 291-294

Adikwu E, Deo O, Oru-Bo, Geoffrey OBP, Enimeya DA (2013). Lead organ and tissue toxicity: roles of mitigating agents (part 1). British Journal of Pharmacology and Toxicology 4, 232-240

Almarmudah M (2009). Pengaruh pemberian plumbum asetat terhadap jumlah sel spermatogenik dan sel Sertoli pada mencit (Mus musculus) jantan. Surabaya, Universitas Airlangga

Amic D, Davidovic-Amic D, Beslo D, Trinasjtic N (2003). Structure-radical scaveging activity relationshipof flavonoids. Croatica Chemica Acta 76

Ardyanto D (2005). Deteksi pencemaran timah hitam (Pb) dalam darah masyarakat yang terpajan timbal (plumbum). Jurnal Kesehatan Lingkungan 2, 67-76

Astawan M, Kasih AL (2008). Khasiat warna-warni makanan. Jakarta, Gramedia Pustaka Umum

Bouayed J, Bohn T (2010). Exogenous antioxidantsdouble-edged swords in cellular redox state: Health beneficial effects at physiologic doses versus deleterious effects at high doses. Oxidative medicine and cellular longevity 3, 228-237

Bustos-Obregon E, Hartley BR (2008). Ecotoxicology and testicular damage (environmental chemicall pollution). Int. J. Morphol 26

Camin R (1993). Pengaruh pemberian plumbum asetat intragaster terhadap spermatogenesis, kualitas spermatozoa dan kadar plumbum dalam darah tikus. Jakarta, Universitas Indonesia

Cao G, Sofic E, Prior RL (1997). Antioxidant and prooxidant behavior of flavonoids: structure-activity relationships. Free Radic Biol Med. 22, Issue 5: 749760

Defalco T, Anirudh S, Anaïs B, Iruela-Arispe ML, Blanche C (2013). Testosterone levels influence mouse fetal Leydig cell progenitors through notch signaling. Biology of Reproduction 88, 91

Flora G, Gupta D, Tiwari A (2012). Toxicity of lead: a review with recent updates. Journal list Interdiscip Toxicol 5, 47-58

Hattenschwiller S, Vitousek PM (2000). The role of polyphenols interrestrial ecosystem nutrient cycling. TREE 15

Jamilah B, Shu CE, Kharidah M, Dzulkify MA, Noranizan A (2011). Physico-chemical characteristics of red pitaya (Hylocereus polyrhizus) peel. International Food Research Journal 18, 279-286

Kumalaningsih S (2006). Antioksidan alam penangkal radikal bebas sumber, manfaat, cara penyediaan dan pengelolaan. Surabaya, Trubus Agriwidya
Le Bellec F, Vaillant F, and Imbert E (2006). Pitaya (Hylocereus spp.): a new fruit crop, a marker with a future. Journal of Fruit 6, 237-250

Lyn P (2006). Lead toxicity part II: the role of free radical damage and the use of antioxidants in the pathology and treatment of lead toxicity. Alternative Medicine Review 11, 114-127

Mahriani, 2008. Kajian ekspresi protein bax pada gangguan spermatogenesis pasca pemaparan 2,5 hexanadione pada tikus putih (Rattus novergicus). Jurnal Biologi 7, 1-5

Martínez R, Torres P, Meneses M, Figueroa JG, PérezÁlvarez JA, Viuda-Martos M (2012). Chemical, technological and in vitro antioxidant properties of mango, guava, pineapple and passion fruit dietary fibre concentrate. Food Chemistry 135, 1520-1526

Mayo, 2005. Diseases and conditions; infertility. Mayo Foundation for Medical Education and Research (MFMER), 1-3.

Mitasari A (2012). Uji aktivitas ekstrak kloroform kulit buah naga merah (Hylocereus polyrhizus Britton \& Rose) menggunakan metode DPPH (1,1-Defenil-2Pikril Hidrazil). Pontianak, Universitas Tanjungpura

Murat B, Selim S, Cavit K, Deniz K, Funda K, Hande SY, Mehmet A, Ferda A (2014). The protective effects of vitamin $\mathrm{C}$ on the DNA damage, hyperhomocysteinemia induced rats. Experimental and Toxicologic Pathology 60, 407-413

Murray RK, Granner DK, Mayyes PA, Rodwell VW (2003). Biokimia harper. 25th Ed. Jakarta, EGC

Hsu PC, Guo YL (2002). Antioxidant nutrients and lead toxicity. Toxicology 180, 33-44

Naria E (2005). Mewaspadai dampak bahan pencemar plumbum $(\mathrm{Pb})$ di lingkungan terhadap kesehatan. Jurnal Komunikasi Penelitian 17

Nurliyana R, Syed ZI, Mustapha SK, Aisyah MR, Kamarul RK (2010). Antioxidant study of pulp and peel dragon fruits: a comparative study. International Food Research Journal 17, 365-375

Palar H (2008). Pencemaran dan toksikologi logam berat. Jakarta, Rineka Cipta

Panggabean PCT, Soeng S, Ivone J (2008). Efek pajanan timbal terhadap infertilitas pria. JKM 8

Pieta PG (2000). Flavonoids as anti-oxidants. J. Nat. Prod., 1043-1046

Prakash A (2001). Antioxidant activity. Medallion Laboratories Analytical Progress 19

Roman M, Kaczor A, Dobrowolski JC, Baranska M (2013). Structural changes of b-carotene and some retinoid pharmaceuticals induced by environmental factors. Journal of Molecular Structure 1037, 99-108

Shan G, Tang T, Zhang X (2009). The protective effect of ascorbic acid and thiamine supplementation against damage caused by lead in the testes of mice. J. Hazhong Univ. Sci. Technol. Med. Sci. 29, 68-72 
Sudarmaji, Mukono J, Corie IP (2006). Toksikologi logam berat b3 dan dampaknya terhadap kesehatan. jurnal kesehatan lingkungan, 129-142

Sumardika IW, Jawi IM (2012). Ekstrak air daun ubi jalar ungu memperbaiki profil lipid dan meningkatkan kadar SOD darah tikus yang diberi makanan tinggi kolestrol. Jurnal Ilmiah Kedokteran Medicina 43, 6771

Suparwoko, Firdaus F (2007). Profil pencemaran udara kawasan perkotaan Yogyakarta: studi kasus di kawasan Malioboro, Kridosono, dan UGM Yogyakarta. LOGIKA 4

Telisman S, Cvitkovic P, Jurasovic J, Pizent A, Gavella M, Rocic B (2000). Semen quality and reproductive endocrine function in relation to biomarkers of lead, cadmium, zinc, and copper in men. Environmental Health Perspectives, 45-53

Vermerris W, Nicholson R (2006). Phenolic compound biochemistry. Dordrecht, Springer

WHO (World Health Organisation) (2007). Lead exposure in children. Geneva, WHO

Winarno FG (1997). Kimia pangan dan gizi. Jakarta, PT. Gramedia

Wu LC, Hsu HW, Chen YC, Chiu CC, Lin YI, Ho JA (2006). Antioxidant and antiproliferative activities of red pitaya. Food chemistry 95, 319-327 